\title{
Using AHP to Prioritize Barriers in Developing Medical Tourism: Case of Turkey
}

\author{
Doğancan Çavmak ${ }^{*}$, Şeyda Çavmak² \\ ${ }^{1}$ Healthcare Management Department, Vocational School of Healthcare Services, Tarsus University, Mersin, Turkey \\ ${ }^{2}$ Medical Documentation and Secretarial Department, Vocational School, Cag University, Mersin, Turkey
}

Corresponding Author: Doğancan Çavmak, PhD Candidate, Healthcare Management Department, Vocational School of Healthcare Services, Tarsus University, Mersin, Turkey. Tel: +90-5452634664, Email: dogancavmak@tarsus.edu.tr

Received December 25, 2019; Accepted April 16, 2020; Online Published May 31, 2020

\begin{abstract}
Introduction: In the globalizing world; the concept of medical tourism comes to the fore with the increase in travel freedoms between countries, easier transportation facilities, and the increased quality of healthcare services in different countries. This study aims to examine the barriers to developing medical tourism and prioritize the factors to give an insight on where to allocate resources in the scope of a conceptual framework on medical tourism.

Methods: Barriers to medical tourism in Turkey were identified based on the literature and experts' opinions. As a result of the expert opinions, 23 factors were identified and grouped under five main categories. The analytical hierarchy process method was used to prioritize the factors. A pair-wise comparison form was prepared by the researcher and sent to experts. The data obtained from these forms was analyzed and weights were calculated.

Results: The factors were ranked from most important to least important as follows: negative corporate image ( $w=0.319)$, quality of healthcare $(w=0.198)$, incompatible regulations/law $(w=0.177)$, human resources $(w=0.163)$, and underdeveloped infrastructure $(\mathrm{w}=0.142)$.

Conclusion: It was determined that the development of medical tourism is not sufficient, despite the great potential of Turkey in terms of technological healthcare services and attractiveness of tourism destinations. Major attempts should be made in marketing to attract medical tourists.

Keywords: Health Tourism, Medical Tourists, Turkey
\end{abstract}

Citation: Çavmak D, Çavmak Ş. Using AHP to prioritize barriers in developing medical tourism: case of Turkey. Int J Travel Med Glob Health. 2020;8(2):73-79. doi:10.34172/ijtmgh.2020.12.

\section{Introduction}

Health tourism is a very broad concept, one that refers mainly to one's organized travel abroad from a local environment with the aim of maintaining or improving one's wellbeing and health status. According to different definitions, health tourism is related to any tourism activities which involve relieving an individual's stress ${ }^{1}$ as related to the individual's general health and wellbeing. ${ }^{2}$ Medical tourism is a type of health tourism and a relatively new term when compared to the general concept of health tourism. Medical tourism is strongly related to medical procedures, such as screening, treatment, or surgical operations. ${ }^{3}$

The concepts of "tourist" and "health" intersect in a variety of relations. Cohen ${ }^{4}$ identified a fivefold typology: mere tourist (1), medicated tourist (2), medical tourist proper (3), vacationing patient (4), and mere patient (5). This typology is built on the extent of medical treatment in an individual's motivation for traveling. A mere tourist is one who does not receive any kind of medical service at the destination or during their sojourn, while a mere patient is one who travels solely to obtain medical treatment and does not take advantage of any vacationing opportunities in the destination country. The other typologies between these two poles result from the relationship between medical treatment and tourism activities. "Medical tourist proper" refers to an individual who travels with the aim of both tourism and medical treatment. The current study has focused on this typology due to its conformity with medical tourism.

Medical tourism has gained considerable attention around the globe. Although the direction of travels for medical treatment was to developed countries, especially by wealthy people, many patients have recently traveled from developed countries to underdeveloped and developing ones because of the increasing prices of healthcare in developed countries. Globalization has allowed populations to search for cheaper medical treatments in other countries. The opportunity to

Copyright $($ C 2020 The Author(s). This is an open-access article distributed under the terms of the Creative Commons Attribution License (http:// creativecommons.org/licenses/by/4.0), which permits unrestricted use, distribution, and reproduction in any medium, provided the original work is properly cited. 
experience a historical trip, learn about other cultures, or enjoy nice beaches while obtaining medical treatment has also attracted many people around the world. Many countries have been investing on medical technologies and qualified human resources to receive more medical tourists. ${ }^{5}$ The saying of Yuasa, "Catch some sun, take in a few golden temples, and get a new hip,"6 best summarizes medical tourism.

Several effects of medical tourism in both destination and departure countries have been identified. Medical tourism is a beneficial industry which provides a considerable income for the destination country. It may relieve the public sector and allocate more resources to the private sector. Investing in the infrastructure of healthcare services for medical tourism may enhance the benefits to local patients as well. Adopting the international standards for accreditation in destination countries may alter the conceptions and standards of healthcare in departure countries as well. Other than these constructive effects, medical tourism can also lead to an inequality in the provision of healthcare services in destination countries. ${ }^{7}$ Investments in healthcare may be limited to urban areas. Moreover, it may cause a brain drain of the health workforce to urban areas and within countries. ${ }^{8}$

Several factors should be carefully considered when seeking to achieve success in medical tourism. Figure 1 presents a comprehensive approach to medical tourism success. ${ }^{9}$

The quality of medical treatment and the comfort of the patient are the most important elements in the attractiveness of a destination. Quality in medical tourism includes many dimensions, such as access, accreditation, appropriateness, effectiveness, equality, equity, safety, timeliness, and so on. ${ }^{10}$ Wait times and prices of healthcare services are other prominent determinants of success in medical tourism. ${ }^{7}$ Another important factor that must be considered is the existence of adequate and qualified medical travel facilitators. These organizations play a key role in the relationship between patients and healthcare facilities/hospitals. Medical travel facilitators can enhance the attractiveness of a destination through their initiatives. The web page contents of facilitators must allow users to access accredited healthcare facilities, gain information about treatment plans, and include information

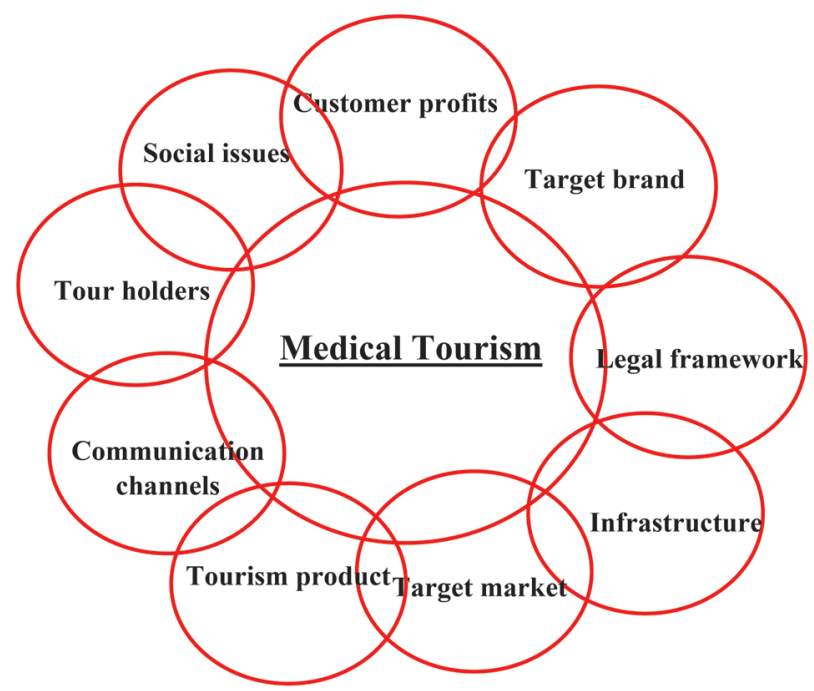

Figure 1. Factors Related. on tourist sites and opportunities in destinations. ${ }^{11}$ It has been indicated that interactive web pages can ease the process of building a bridge between patients and healthcare facilities. ${ }^{12}$

\section{Current Status of Turkey in Medical Tourism}

Turkey is ranked eighth in number of tourists visiting the country and 14th in tourism receipts around the world. ${ }^{13}$ This suggests that tourists who visit Turkey spend less than tourists in other countries, especially European ones. This fact hints that the middle and lower income groups comprise the majority of tourists visiting Turkey. However, the great number of visitors should be seen as a potential for integration of tourism and the medical sector.

Many studies have examined the medical tourism status of Turkey in the world and identified lower costs, attractiveness of general tourism, wide transportation infrastructure, and high number of accredited health facilities as Turkey's strengths. Its weaknesses are a lack of facilitators, legally compliance problems, inadequate experience in medical tourism, and a lack of integration. ${ }^{14}$ According to the 2020 data of the Joint Commission International (JCI), Turkey has 34 accredited health facilities. When compared to countries such as Thailand (62 accredited health facilities), Singapore (8 accredited facilities), and India (34 accredited facilities) which have the highest medical tourism receipts, Turkey's health care facilities and health infrastructure are quite suitable for medical tourism. ${ }^{15}$

The number of tourists and tourism receipts are shown in Table $1 .^{16}$

The number of health tourists has noticeably increased over the years; however, the share of total receipts that health tourism comprises is not satisfying. A normal tourist spends an average of $\$ 665$, while a medical tourist spends an average of $\$ 1608$ per trip. ${ }^{16}$

Turkey is one of the top ten tourism destinations around the world (https://www.amjmed.com/action/ showPdf?pii=S0002-9343\%2818\%2930620-X). Most medical tourists in Turkey come from nearby countries (Libya, Azerbaijan) or countries that have large Turkish populations (Germany). In addition, most arrivals are not in the context of medical tourism, but the health of tourists. ${ }^{17}$

The current study investigated the barriers to medical tourism and prioritized them. The study also aimed to shed light on how medical tourism in Turkey can be improved based on the given conceptual framework. The study further sought to answer the following questions:

1. What are the barriers to medical tourism in Turkey?

2. Which barriers are most important?

3. What should be done to overcome the barriers to medical tourism?

\section{Methods}

This study is a mix of quantitative and qualitative approaches. The qualitative process was conducted to determine the barriers to medical tourism in the first phase. A model was shaped based on interviews so as to conduct the analytic hierarchy process (AHP). In the second phase, AHP was conducted so as to prioritize the identified barriers. 
Table 1. Number of Tourists and Tourism Receipts

\begin{tabular}{|c|c|c|c|c|}
\hline & Number of Tourists & Tourism Receipts (\$1000) & Number of Health Tourists & Health Tourism Receipts (\$1000) \\
\hline 2003 & 16302048 & 13854868 & 139971 & 203703 \\
\hline 2005 & 24124504 & 20322110 & 220338 & 343181 \\
\hline 2007 & 27214986 & 20942500 & 198554 & 441677 \\
\hline 2009 & 32006140 & 25064481 & 201222 & 447296 \\
\hline 2011 & 36151328 & 28115694 & 187363 & 488443 \\
\hline 2013 & 39226226 & 32308991 & 267461 & 772901 \\
\hline 2015 & 41617530 & 31464770 & 360180 & 638622 \\
\hline 2017 & 38620346 & 26283656 & 433292 & 827331 \\
\hline 2019 & 51860042 & 34520332 & 662087 & 1065105 \\
\hline
\end{tabular}

\section{Sampling Process}

Attempts were made to obtain a sample as suitable as possible to the study's objectives. The main strategy was to include both scholars and sector professionals to achieve accurate results. Hospital professionals who are in charge of or work for medical tourism in Istanbul were sought because of Istanbul's importance in medical tourism visitors/receipts and the high number of hospitals in Istanbul that are certified for medical tourism. Attempts were also made to include professionals from both private and public hospitals so as to obtain a more representative sample of the universe.

The first phase of the study included 4 participants consisting of 2 academicians and 2 experts from 2 separate private hospitals in Istanbul which are approved for medical tourism by the Ministry of Health (Table 2).

\section{Qualitative Analysis}

Interviews were conducted via electronic mail. Participants were asked to list the barriers to medical tourism in Turkey regardless of their rank of importance. The question of the interview was, "What kinds of barriers to the development of medical tourism in Turkey can you see?" Interviewees were also asked, "Please list the barriers you name, regardless of their importance, and add additional comments separately if you find it necessary." The main purpose of these interviews was to obtain a long list of barriers from a variety of professional areas in order to shape a hierarchical model.

A basic thematic analysis was conducted to identify the patterns of meaning in the data. An inductive perspective was considered. Coding was undertaken manually. First, duplicates or strongly similar expressions in terms of their meanings were determined. Lists of barriers and additional comments were analyzed separately. After the analysis, a total of 23 expressed barriers were listed. Then, a further analysis was conducted to identify those barriers highly related to each other in order to create main themes as the main factors of the AHP model. A model with 5 main barrier factors and 23 barriers to rank was acquired using AHP.

\section{Quantitative Analysis}

The second phase of the study was based on AHP, which is a quantitative technique for analyzing multicriterial and complex decisions. It enables researchers to quantify the weights of criteria or factors related to decision making. AHP is carried out by pair-wise comparison of criteria. ${ }^{18,19}$ Some advantages of AHP include the possibility to include many criteria, adaptability to different problems, and no need for a high quantity of data. ${ }^{18}$

The first phase of AHP was to determine the objective and criteria, and the second aimed to compare a pair of criteria on a single property. This is an effort to concentrate on an effective judgment of the criteria. ${ }^{19}$ The criteria were compared based on the experts' opinions. To turn subjective evaluations of the participants into quantitative data, a scale of 1-9 was used for each pair-wise comparison (Table 3). ${ }^{19}$ The process was continued with the steps of obtaining the comparison matrix, normalizing the matrix, and calculating the priority vector and consistency ratio (CR). ${ }^{17} \mathrm{CR}$ is used to conclude whether matrices are acceptable. It is calculated based on the consistency index (CI), which is the index of consistency of judgments across all pair-wise comparisons. A CR equal to or less than $10 \%$ indicates inconsistency, and so matrices are acceptable. ${ }^{21}$

Two academicians, 2 medical tourism experts from a public hospital, one expert from a private hospital in Istanbul, and a member of the Health Tourism Coordination Committee agreed to participate in this phase of the study. Participants were informed about the purpose of the study and the AHP. Pair-wise comparison forms were sent to all participants. The weights of factors and consistency ratios were calculated

Table 2. Participants of Qualitative Phase

\begin{tabular}{ll}
\hline Participants & Features \\
\hline Scholar 1 & $\begin{array}{l}\text { His research fields are healthcare management and health tourism. He is a PhD candidate and has been conducting scientific studies on medical } \\
\text { tourism. }\end{array}$ \\
Scholar 2 & She is an assistant professor doctor. She has a PhD degree in healthcare management and is currently studying medical tourism and marketing. \\
Expert 1 & $\begin{array}{l}\text { He has been working as an expert in a private hospital in Istanbul. He has } 5 \text { years of experience in hospitals in quality and international marketing } \\
\text { departments and is currently working on medical tourism in his hospital. }\end{array}$ \\
Expert 2 & $\begin{array}{l}\text { He has } 6 \text { years of experience in private hospitals. He has worked in human resources and patients services department as a manager. He currently } \\
\text { organizes medical tourism in the hospital where he works. }\end{array}$ \\
\hline
\end{tabular}


Table 3. The Fundamental Scale

\begin{tabular}{lc}
\hline Definition & Explanation \\
\hline Equal importance & 1 \\
Moderate importance of one over another & 3 \\
Essential or strong importance & 5 \\
Very strong importance & 7 \\
Extreme importance & 9 \\
Intermediate values & $2,4,6,8$ \\
\hline
\end{tabular}

separately for each participant. At first implications, unacceptable inconsistency ratios were detected for two participants. The 2 participants were asked to evaluate the comparisons again, and the revised forms were obtained. The model was analyzed using Microsoft Excel 2010 program (Table 4).

\section{Results}

The answers of participants about barriers to medical tourism in Turkey were reviewed and organized into meaningful main components. The most emphasized barriers based on the answers were inadequate human resources in medical tourism, negative corporate image and perceptions of Turkey in the world, the lack of facilitators, and unsatisfactory quality of care for medical tourists. The main expressed problems in human resources was the inability to properly communicate and insensitivity to tourists' cultural features and habits. Many participants focused on the image of the country and perceptions of Turkey's political, cultural, and social dimensions. It was seen that the geography where Turkey is located has a significant effect on the perception of Turkey according to participants' evaluations. Terrorist events on the border of Turkey and political ambiguity in neighboring countries have negative effects on Turkey. Most participants emphasized that Turkey's marketing efforts in medical tourism were not sufficient for shaping a better perception, even though Turkey has strongly developed and technological healthcare. Another barrier strongly related to marketing efforts was the lack of medical tourism facilitators. There are two sides to this barrier. First, there are not enough facilitators in term of quantity, and secondly, their quality is questionable. According to most participants, the existing facilitators are not capable of planning an integrated medical care and tourism activities, and their web pages are not user-friendly. Another aspect is the insufficient network of facilitators. The lack of facilitators is seen as the prominent determinant for the problem of integrating general tourism trips and medical tourism. According to the participants, the potential of tourism attractiveness can moderate the development of medical tourism. Yet another barrier determined was related to legislation and regulations. Participants evaluated the regulations on medical tourism as incompatible with international medical tourism implications.

In this study, an AHP model was developed based on the answers of the participants as discussed above. The model consisted of 5 main factors and 23 sub-factors. The main factors were: (1) problems related to human resources, (2) under-developed infrastructure, (3) incompatibility of regulations/law, (4) negative image, and (5) quality and provision of healthcare services (Figure 2).

First, the 5 main factors were subjected to pair-wise comparison, and inconsistency ratios were calculated. Then, the sub-factors in each main factor were subjected to the same process. Weights were calculated for each participant separately. Then, to synthetize individuals' evaluations, the arithmetic mean was calculated. The results are shown in Table 5 .

The consistency matrix was found to be acceptable, because all $\mathrm{CR}$ values were equal or less than 0.10 . The factors were ranked from most important to least important as follows: negative corporate image $(\mathrm{w}=0.319)$, quality of healthcare $(\mathrm{w}=0.198)$, incompatible regulations/law $(\mathrm{w}=0.177)$, human resources $(\mathrm{w}=0.163)$, and underdeveloped infrastructure $(\mathrm{w}=0.142)$.

The most important factor identified under corporate image was fear of terror attacks $(\mathrm{w}=0.294)$ and under quality of healthcare was low quality of healthcare $(w=0.548)$. In the incompatible regulations factors, the most important variable was insufficient agreements on medical tourism $(\mathrm{w}=0.356)$. Language problem had the highest weight $(\mathrm{w}=0.372)$ under the human resources factor, and lack of facilitators was the most important factor $(\mathrm{w}=0.353)$ under underdeveloped infrastructure (Table 6).

\section{Discussion}

The current paper purposed to contribute to the understanding

Table 4. Participants of AHP Phase

\begin{tabular}{|c|c|}
\hline Participants & Features \\
\hline Scholar 1 & $\begin{array}{l}\text { His research fields are healthcare management and health tourism. He is a PhD candidate and has been conducting scientific studies } \\
\text { on medical tourism. }\end{array}$ \\
\hline Scholar 2 & $\begin{array}{l}\text { She is an assistant professor doctor. She has a PhD degree in healthcare management and is currently studying medical tourism and } \\
\text { marketing. }\end{array}$ \\
\hline Expert 1 (private hospital) & $\begin{array}{l}\text { He has } 6 \text { years of experience in private hospitals. He has worked in human resources and patients services department as a manager. He } \\
\text { currently organizes medical tourism in the hospital where he works. }\end{array}$ \\
\hline Expert 2 (public hospital) & $\begin{array}{l}\text { She has about } 7 \text { years of experience in the managerial departments of public hospitals. She has been working on the process of gaining } \\
\text { medical tourism receipts and arranging required documentation. }\end{array}$ \\
\hline Expert 3 (public hospital) & $\begin{array}{l}\text { He has } 5 \text { years of experience in quality management at a public hospital and is currently a member of the medical tourism committee } \\
\text { in a hospital. }\end{array}$ \\
\hline $\begin{array}{l}\text { Member of Health Tourism } \\
\text { Coordination Committee }\end{array}$ & $\begin{array}{l}\text { He has } 15 \text { years of experience in healthcare management. He is a professional consultant focusing on hospital management and medical } \\
\text { tourism. He is a member of the Health Tourism Coordination Committee in the Ministry of Health. }\end{array}$ \\
\hline
\end{tabular}




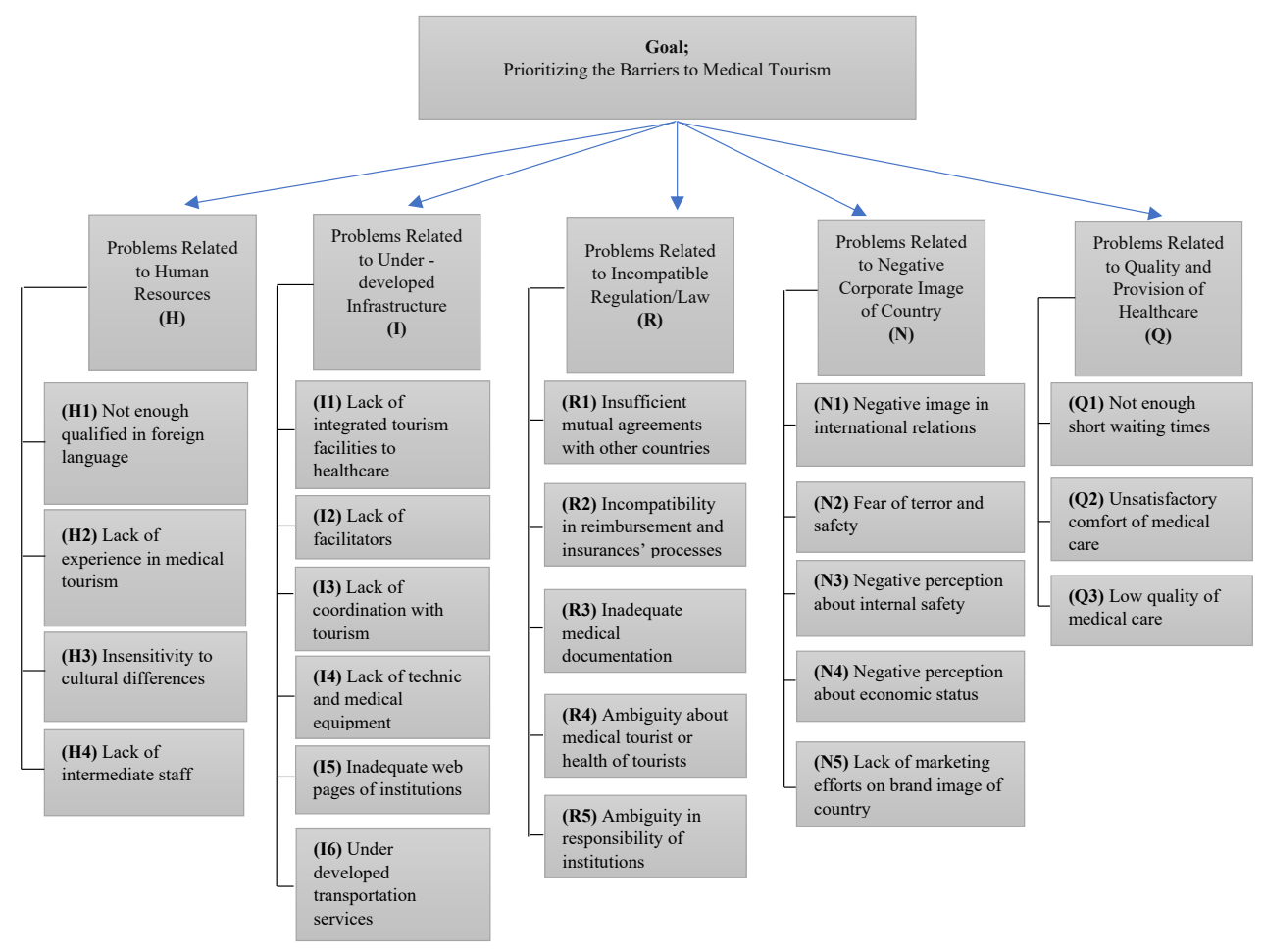

Figure 2. AHP Model of the Study.

of medical tourism in Turkey by determining the barriers to its development and prioritizing them. The results of qualitative and quantitative approaches were synthetized. The synthetized approach allowed the evaluation of relationships other than prioritization between barriers. The results revealed that the main barrier to developing medical tourism in Turkey was the negative perception of brand and political image, which were strongly related to inadequate and inefficient marketing efforts. The negative perception was found to be related mainly to safety issues owing to the political instability and chaos at the Turkey's borders. Many participants indicated that Turkey has great opportunities and strengths compatible with medical tourism, but they are not promoted properly so as to attract more medical visitors. The participants also emphasized that the marketing of Turkish healthcare technology and healthcare system which should be integrated with tourism activities such as historical trips, religion tourism, and natural beauties should be a focal point. These findings were consistent with some studies conducted in Turkey using the integrated AHP-SWOT model. The weaknesses and threats determined by these studies were similar to those of the current study. In addition, these studies concluded that Turkey must focus on its strengths to make significant progress in health and medical tourism. ${ }^{13}$ The authors believe that there is a relation between integrating medical care and tourism and facilitators. There is evidence of the moderating effects of facilitators on medical tourism. The role of facilitators as a negotiator between patients and hospitals has a direct influence and positive effects on the effectiveness of medical tourism. ${ }^{22}$ In interviews with participants, it was determined that the lack of medical tourism facilitators was a prominent factor for insufficient information about Turkey. Some problems identified with facilitators were being scarce, being underqualified, insufficient experienced human resources, and insufficient legislative regulations.

Some studies have suggested that medical tourism requires an extensive and intensive information exchange and counseling. The communication between visitors/ patients and the healthcare workforce must be effective so as to allow patients to become involved in the decisionmaking progress. ${ }^{23}$ Some studies have indicated that being able to communicate in a patient's native language plays an

Table 5. Weights of Factors

\begin{tabular}{|c|c|c|c|c|c|c|}
\hline \multirow{2}{*}{ Participants } & \multicolumn{6}{|c|}{ Main Factors } \\
\hline & $\mathbf{H}$ & $I$ & $\mathbf{R}$ & $\mathbf{N}$ & $\mathbf{Q}$ & CR \\
\hline 1 & 0.122516 & 0.253683 & 0.064851 & 0.105187 & 0.453763 & 0.0942 \\
\hline 2 & 0.110497 & 0.259616 & 0.037134 & 0.150534 & 0.442218 & 0.0998 \\
\hline 3 & 0.345691 & 0.056175 & 0.112416 & 0.355548 & 0.130169 & 0.0463 \\
\hline 4 & 0.05707 & 0.173762 & 0.190885 & 0.538498 & 0.039785 & 0.0495 \\
\hline 5 & 0.193202 & 0.058669 & 0.152543 & 0.560989 & 0.034597 & 0.097 \\
\hline 6 & 0.149586 & 0.050769 & 0.506588 & 0.204125 & 0.088933 & 0.101 \\
\hline Average Weights & 0.163094 & 0.142112 & 0.177403 & 0.319147 & 0.198244 & - \\
\hline
\end{tabular}


Table 6. Weights of Sub-Factors

\begin{tabular}{|c|c|}
\hline \multirow{4}{*}{$\begin{array}{l}\text { Human resources } \\
(\mathrm{H}), \mathrm{w}=0.1630\end{array}$} & Insufficiently qualified in foreign language $(\mathrm{w}=0.372)$ \\
\hline & Lack of experience in medical tourism $(\mathrm{W}=0.252)$ \\
\hline & Insensitivity to cultural differences $(w=0.202)$ \\
\hline & Lack of intermediate staff $(\mathrm{w}=0.164)$ \\
\hline \multirow{6}{*}{$\begin{array}{l}\text { Infrastructure (I), } \\
W=0.1422\end{array}$} & $\begin{array}{l}\text { Lack of integrated tourism facilities to healthcare } \\
\text { institutions }(w=0.09)\end{array}$ \\
\hline & Lack of facilitators $(\mathrm{w}=0.353)$ \\
\hline & Lack of coordination with tourism $(\mathrm{w}=0.082)$ \\
\hline & Lack of technical and medical equipment $(\mathrm{w}=0.16)$ \\
\hline & Inadequate web pages of institutions $(w=0.24)$ \\
\hline & Underdeveloped transportation services $(\mathrm{w}=0.075)$ \\
\hline \multirow{5}{*}{$\begin{array}{l}\text { Regulations }(R), \\
w=0.1774\end{array}$} & $\begin{array}{l}\text { Insufficient mutual agreements with other countries } \\
(\mathrm{W}=0.356)\end{array}$ \\
\hline & $\begin{array}{l}\text { Incompatibility in reimbursement and insurance } \\
\text { processes }(\mathrm{W}=0.254)\end{array}$ \\
\hline & Inadequate medical documentation $(\mathrm{w}=0.050)$ \\
\hline & $\begin{array}{l}\text { Ambiguity about medical tourist or health of tourists } \\
(\mathrm{w}=0.126)\end{array}$ \\
\hline & Ambiguity in responsibility of institutions $(\mathrm{w}=0.212)$ \\
\hline \multirow{5}{*}{$\begin{array}{l}\text { Negative corporate } \\
\text { image }(\mathrm{N}) \\
\mathrm{W}=0.3191\end{array}$} & Negative image in international relations $(\mathrm{w}=0.24)$ \\
\hline & Fear of terror and safety $(w=0.294)$ \\
\hline & Negative perception about internal safety $(\mathrm{w}=0.25)$ \\
\hline & Negative perception about economic status $(\mathrm{w}=0.04)$ \\
\hline & $\begin{array}{l}\text { Lack of marketing efforts on brand image of country } \\
(w=0.173)\end{array}$ \\
\hline \multirow{3}{*}{$\begin{array}{l}\text { Quality and } \\
\text { provision of } \\
\text { healthcare (Q), } \\
\mathrm{w}=0.1982\end{array}$} & Not enough short wait times $(\mathrm{w}=0.178)$ \\
\hline & Unsatisfactory comfort of medical care $(\mathrm{w}=0.272)$ \\
\hline & Low quality of medical care $(\mathrm{w}=0.548)$ \\
\hline
\end{tabular}

important role in satisfaction. ${ }^{24}$ The current study revealed that the main problem of human resources in Turkey's healthcare system and medical tourism involved language and communication skills. Foreign language proficiency of human resources were indicated as being insufficient. This problem in communication results in a negative perception of the accessibility and appropriateness of healthcare services. Cultural competence is another important issue related to human resources. Evidence on the cultural aspects of medical tourism suggest that physician-patient communication should be culturally oriented. ${ }^{25}$ The current results revealed that sensitivity to cultural features is lacking in the human resources of medical tourism in Turkey.

\section{Conclusion}

Turkey has a significant potential for medical tourism; however, it receives fewer medical tourists than other Asian countries which are similar to Turkey in terms of healthcare technology and even attractiveness of general tourism. The current study revealed some barriers which may be valid in other countries as well and can contribute to the understanding of medical tourism.

Some actions are proposed based on barriers to increasing Turkey's medical tourism attractiveness. First, an effective marketing plan must be designed at the national level, especially one that engages the ministries of health and culture and tourism. There is a significant role of marketing for facilitators. Regulations and incentives for facilitators should be negotiated with the participation of all stakeholders.

\section{Research Highlights}

\section{What Is Already Known?}

The literature on evaluating medical tourism with AHP and SWOT analysis in Turkey indicated that Turkey has some weaknesses, such as lack of coordination and marketing efforts and inadequate quality of human resources..

\section{What This Study Adds?}

This study provides a deeper insight into the barriers, including weaknesses of and threats to medical tourism. The findings also prioritizes barriers to be used for more accurate resource allocation.

There is a need to improve the quality of human resources. It is recommended that healthcare providers arrange some education for their employees in communication skills and cultural competence.

\section{Authors' Contributions}

DC was responsible for the concept of the study. DC created the main approach to the study and prepared the main manuscript. SC was responsible for data collection and arrangement of the manuscript in journal format. Both authors were responsible for qualitative analysis. DC conducted the quantitative analysis.

\section{Conflict of Interest Disclosures}

The authors declare no conflicts of interest.

\section{Ethical Approval}

The study was approved by the Scientific Researches and Ethical Committee of Tarsus University, Mersin, Turkey.

\section{Funding/Support}

None.

\section{References}

1. Bennett $M$, King B, Milner L. The health resort sector in Australia: a positioning study. J Vacat Mark. 2004;10(2):122-137. doi:10.1177/135676670401000203.

2. Connell J. Medical tourism: sea, sun, sand and ... surgery. Tour Manag. 2006;27(6):1093-1100.doi:10.1016/j.tourman.2005.11.005.

3. Henderson JC. Healthcare tourism in Southeast Asia. Tour Rev Int. 2003;7(3-4):111-121. doi:10.4324/9781315029115.

4. Cohen E. Medical tourism in Thailand. AU-GSB e-Journal. 2008;1(1):24-37.

5. Lunt N, Smith R, Exworthy M, Green ST, Horsfall D, Mannion R. Medical Tourism: Treatments, Markets and Health System Implications: A Scoping Review. Paris: Organisation for Economic Co-operation and Development; 2011.

6. Yuasa S. Medical tourism booming in Asia. https://www.iol.co.za/ travel/medical-tourism-booming-in-asia-876914. Accessed April 11, 2020. Published 2005.

7. Johnston R, Crooks VA, Snyder J, Kingsbury P. What is known about the effects of medical tourism in destination and departure countries? a scoping review. Int J Equity Health. 2010;9:24. doi:10.1186/1475-9276-9-24.

8. Ghanbari A, Zirak Moradlu K, Ramazani M. Medical tourism. Manag Sci Lett. 2014;4(8):1651-1654. 
9. Turner LG. Quality in health care and globalization of health services: accreditation and regulatory oversight of medical tourism companies. Int J Qual Health Care. 2011;23(1):1-7. doi:10.1093/ intqhc/mzq078.

10. Woodhead A. Scoping medical tourism and international hospital accreditation growth. Int J Health Care Qual Assur. 2013;26(8):688702.doi:10.1108/ijhcqa-10-2011-0060.

11. Cormany D, Baloglu S. Medical travel facilitator websites: an exploratory study of web page contents and services offered to the prospective medical tourist. Tour Manag. 2011;32(4):709-716. doi:10.1016/j.tourman.2010.02.008.

12. Cortez N. Patients without borders: the emerging global market for patients and the evolution of modern health care. Indiana Law J. 2008;83(1):71-132.

13. TYYD. World Tourism2018. http://ttyd.org.tr/tr/turizm-istatistikleri. Accessed April 4, 2020.

14. Aydın G, Aydın BK. Comparative situation analysis and marketing applications in healthcare tourism around the globe and in Turkey. Pazarlama ve Pazarlama Araştırmaları Dergisi. 2015;16:1-21. [Turkish].

15. JCl-Accredited Organizations. https://www.jointcommissioninternational.org/about-jci/accredited-organizations/ Accessed April 4, 2020.

16. Turkish Statistical Institute (TSI). Tourism Statistics. http://www. tuik.gov.tr/PreTablo.do?alt_id=1072. Accessed April 5, 2020. Published 2020.

17. Yıldırım HH, Konca M, Aydın MA, et al. Turkey international patients report 2015-2016 (Turkish). Ankara: Sağlık Bakanlığı,
Sağlık Hizmetleri Genel Müdürlüğü, Sağlık Turizmi Daire Başkanlığı; 2017.

18. Saaty TL. How to make a decision: the analytic hierarchy process. Eur J Oper Res. 1990;48(1):9-26. doi:10.1016/0377$2217(90) 90057-$ I.

19. Saaty RW. The analytic hierarchy process-what it is and how it is used. Math Model. 1987;9(3-5):161-176. doi:10.1016/02700255(87)90473-8.

20. Sharma MJ, Moon I, Bae H. Analytic hierarchy process to assess and optimize distribution network. Appl Math Comput. 2008;202(1):256-265. doi:10.1016/j.amc.2008.02.008.

21. Wang HS, Che ZH, Wu C. Using analytic hierarchy process and particle swarm optimization algorithm for evaluating product plans. Expert Syst Appl. 2010;37(2):1023-1034. doi:10.1016/j. eswa.2009.05.073.

22. Mohamad WN, Omar A, Haron MS. The moderating effect of medical travel facilitators in medical tourism. Procedia Soc Behav Sci. 2012;65:358-363. doi:10.1016/j.sbspro.2012.11.134.

23. Ngamvichaikit A, Beise-Zee R. Communication needs of medical tourists: an exploratory study in Thailand. Int J Pharm Healthc Mark. 2014;8(1):98-117. doi:10.1108/ijphm-10-2012-0010.

24. Röysky M. Overcoming Language Barriers in Health Care Services in the Medical Tourism Context: Health Care Companies' Perspective. Department of Management Studies, Aalto University School of Business; 2015.

25. Liu C, Chen CC. Cultural issues in medical tourism. Am J Tour Res. 2013;2(1):78-83. 